\title{
RESEARCH OF INNOVATIVE POTENTIAL OF THE REGION
}

\author{
Tatiana Sergeevna Kolmykova* \\ Southwest State University, Kursk, Russia \\ Sergey Gennadievich Emelyanov \\ Southwest State University, Kursk, Russia \\ Ekatarina Aleksandrovna Merzlyakova \\ Southwest State University, Kursk, Russia
}

Reference points of innovative development of Russian economy are particularly relevant, outlined in the Concept of Long-Term Social and Economic Development of the Russian Federation in modern conditions. However the regional dimension should be taken into account in the formation of an effective national system due to the territorial characteristics and federal structure. From the perspective of the authors, assessment of innovative potential is the most important procedure in the management of innovative development of the economy of the region. Identification of strengths and weaknesses in resource supply of area allows you to define the priorities of innovative development and justify the use of specific instruments of innovation policy in the region. In this paper we propose author's method of assessment of the region's innovation potential, based on mathematical and statistical tools. Were made the comparative analysis of the innovation potential of the regions of Central Federal District, and analysis of the structure of the regional innovative potential of the Kursk region. The dynamics of the innovation potential of the Central Federal District of subjects for 2005-2015 were considered. Possible measures to enhance the innovative capacity of the region in view of its structural features were defined.

Key words: Region; Economy of the region; Innovation; Region innovation system; Innovation potential of the region.

\section{INTRODUCTION}

The basis of the effectiveness of the national is its innovative potential economy as well as the natural and human resources.

Today the formation of innovation-based economy in Russia restrains a number of factors. Firstly, imbalance in sectoral structure of industry and, as a consequence of extremely low export diversification does not allow to fully participate in the international exchange of high-tech [10, p. 52].

Secondly, the condition of the material and technical base impedes increase of innovation activity of enterprises. First of all, we are talking about the state of fixed assets experiencing enormous need for a full-scale renovation.

Thus, according to the Federal State Statistics Service, depreciation of fixed assets manufacturing industries exceeds $40 \%$. In this case $13-14 \%$ of fixed assets is fully exhausted their resources
$[02$, p. $111 ; 4$, p. $8 ; 8$, p. 26]. The massive rearmament in the majority is the only option for the industrial sector.

Third, the lack of demand for research and development of the business sector has a negative impact on the development of science. Is undisputed that it is scientific knowledge and intellectual potential of society are the generator of ideas embodied in the form of innovation [15; 16 , p. $28 ; 17$, p. $36 ; 18$, p. 39 ]. However, due to the low susceptibility of the private sector to innovate offered by the scientific results are often not use.

The above-mentioned problems in combination with the aggravation of the political situation in the global space and the introduction of economic sanctions against Russia once again emphasize the importance of innovative development of the Russian economy. 
Special place in the formation of the national innovation system (NIS) took a regional dimension, given the complex federal structure of the country and the heterogeneity of the social and economic level of development of its subjects. Moreover regionalization of innovation is closely linked to the processes of globalization.

National boundaries are often blurred taking into account the existing possibilities of companies to move their production operations around the world, taking into account the local advantages of specific regions $[01$, p. $36 ; 3$, p. $85 ; 5$, p. 129 ; 14]. In this regard, the formation of a competitive innovation environment in the region should promote the recruitment and retention of both Russian and foreign investors.

To justify the use of specific innovation policy instruments need a comprehensive assessment of the innovation potential of the region in order to identify the strengths and weaknesses of the resource provision of the subject. Resource possibilities of determine the choice of targets and priorities of innovation development of the region [06, p. 54; 7, p. 21].

\section{METHODS OF THE STRUCTURAL EVALUATION OF REGIONAL INNOVATION POTENTIAL.}

The authors proposed a method of structural evaluation of regional innovation potential (RIP), according to which seven resource blocks can be identified [09, p. 143].

1) The human potential of the region allows us to analyze how regional innovation system is provided by qualified scientific personnel and intellectual resources. The need for evaluation of this block caused by the involvement in the innovation process practically every member of the modern society. This involves not only the ability to develop and implement new scientific ideas and the subsequent development and innovation, but also on the formation of their needs.

2) The scientific potential of the region characterizes the level and scale of research and development in the subject, expressed, including in the establishment of advanced manufacturing technologies.

3) Technical and technological potential determines the possibilities of production in the region of innovation of competitive products, including high-tech. In modern conditions, one of the limiting factors of growth of innovative activity of industrial enterprises stands condition of fixed assets, which should be considered in the analysis of the structural unit.

4) Industrial and production potential of the region is based on an assessment of the volume of industrial production in the region, the rate of growth and innovation orientation.

5) The financial and economic potential of the region characterizes the internal costs of research, development and innovation, the cost of technological innovation, as well as the overall level of economic development of the subject, expressed, for example, at rate of GRP per capita.

6) Investment potential of the region is the basis of the attractiveness of the territory for potential investors. There are several methods of calculating the index. But in this context, we restrict to more important indicators that reflect the volume of investment activity in the region.

7) Information and communication potential of the region allows to evaluate the level of development and the extent of information systems in the region.

Each block includes four indicator description which is presented in Table 1.

The sequence of the structural evaluation of regional innovation potential, consists of five main stages.

The first step is the collection of statistical data, resulting in a set of absolute and relative basic indicators required for the calculation. Evaluation of RIP is totally based on publicly available data of the Federal State Statistics Service, which emphasizes the universality of the developed technique. The next step is computed values calculated partial indicators (RFI), with the definition of specific gravity / share (if required) and subsequent valuation.

It seems appropriate to carry out a valuation metrics using a linear scaling to bring the performance to comparable mean.

Further, integral partial indicators are calculated based on the calculated values of particular indicators for the analyzed period. Principle of the calculation is based on the calculation of the arithmetic mean calculation of particular indicators of the corresponding resource block. Formulas for each specific unit are shown in Table 1. At the last stage the complex integral index of 
Table 1: The system of evaluation of regional innovation potential

\begin{tabular}{|c|c|}
\hline Block & Indicator \\
\hline \multirow{4}{*}{$\begin{array}{l}\text { Human } \\
\text { potential } \\
(\mathrm{HP})\end{array}$} & $\begin{array}{l}\text { HP1 - the ratio of personnel engaged in } \mathrm{R} \& \mathrm{D} \text {, to the number of employed in } \\
\text { the economy }(\%) ;\end{array}$ \\
\hline & $\begin{array}{l}\text { HP2 - the ratio of the number of researchers with advanced degrees to the total } \\
\text { number of researchers }(\%) ;\end{array}$ \\
\hline & HP3 - number of students per 10,000 people. population at year-end (pers.); \\
\hline & HP4 - Issue of postgraduate doctoral studies (with a thesis) (pers.). \\
\hline \multirow{4}{*}{$\begin{array}{l}\text { Scientific } \\
\text { potential } \\
(\mathrm{SP})\end{array}$} & $\begin{array}{l}\text { SP1 - the ratio of the number of institutions that perform scientific R \& D, the } \\
\text { total number of enterprises and organizations, }(\%) ;\end{array}$ \\
\hline & SP2 - patents in the Russian Federation, (pcs.); \\
\hline & $\begin{array}{l}\text { SP3 - the ratio of the number of patents granted to the number of patent ap- } \\
\text { plications filed, }(\%) \text {; }\end{array}$ \\
\hline & SP4 - number of advanced production technology, (pcs.). \\
\hline \multirow{4}{*}{$\begin{array}{l}\text { Techniqu and } \\
\text { technological potential } \\
\text { (TTP) }\end{array}$} & $\begin{array}{l}\text { TTP } 1 \text { - the proportion of organizations implementing technological innovation in } \\
\text { the total number of organizations, }(\%) ;\end{array}$ \\
\hline & TTP2 - used advanced production technology, (pcs.); \\
\hline & $\begin{array}{l}\text { TTP3 - the ratio of the value of fixed assets to the number of employed in the } \\
\text { economy }(\%) ;\end{array}$ \\
\hline & ТТП4 - the degree of depreciation of fixed assets, (\%). \\
\hline \multirow{3}{*}{$\begin{array}{l}\text { Industrial and produc- } \\
\text { tion potential } \\
\text { (IPP) }\end{array}$} & $\begin{array}{l}\text { IPP1 - the ratio of shipped goods, works and services to the economically active } \\
\text { population (\%); }\end{array}$ \\
\hline & $\begin{array}{l}\text { IPP2 - the share of innovative products, works and services in the total volume } \\
\text { of shipped goods, works and services }(\%) ;\end{array}$ \\
\hline & $\begin{array}{l}\text { IPP3 - the ratio of volume of shipped innovative products, works and services } \\
\text { to GRP }(\%) ;\end{array}$ \\
\hline \multirow{4}{*}{$\begin{array}{l}\text { Financial and economic } \\
\text { potential } \\
(\text { FEP) }\end{array}$} & FEP1 - the ratio of expenditure on technological innovation to GRP (\%); \\
\hline & FEP2 - the ratio of the cost of R \& D to the GRP (\%); \\
\hline & FEP3 - GDP per capita (\%); \\
\hline & FEP4 - net financial result (profit minus loss) of organizations, (mln. Rub.). \\
\hline \multirow{4}{*}{$\begin{array}{l}\text { Investment potential } \\
\text { (IP) }\end{array}$} & IP1 - investments in fixed capital per capita, (rub.); \\
\hline & IP2 - the index of physical volume of investments in fixed assets (\%); \\
\hline & IP3 - volume of foreign investments (thousands of US dollars..); \\
\hline & $\begin{array}{l}\text { IP4 - the share of own funds of organizations in the structure of investment in } \\
\text { fixed assets (\%). }\end{array}$ \\
\hline \multirow{4}{*}{$\begin{array}{l}\text { Information and } \\
\text { communication } \\
\text { potential } \\
\text { (ICP) }\end{array}$} & $\begin{array}{l}\text { ICP1 - the proportion of organizations used information and communication } \\
\text { technologies, the total number of organizations surveyed }(\%) ;\end{array}$ \\
\hline & $\begin{array}{l}\text { ICP2 - the proportion of organizations used global information networks, the } \\
\text { total number of organizations surveyed }(\%) ;\end{array}$ \\
\hline & $\begin{array}{l}\text { ICP3 - the proportion of organizations used special software, the total number } \\
\text { of organizations surveyed }(\%) ;\end{array}$ \\
\hline & ICP4 - the number of personal computers per 100 workers (pcs.). \\
\hline
\end{tabular}


evaluation of innovative potential is calculated. RIP is calculated as the seventh root of the product of seven private capacities. A structured approach to the assessment of RIP allows taking into account the degree of readiness of resource supply and a separate block and innovation system in the region as a whole in the design, creation, commercialization and transfer of innovation. With the help of assessment RIP possible to determine the degree and nature of its impact on the economy of the region, on the basis of which it can be adjusted trajectory of regional development [11, p. 53; 12].

\section{APPROBATION OF THE METHODS}

In a research innovation potential levels of the subjects of the CFA were calculated for the years 2005-2015 using the structural evaluation of regional innovation potential. The results are shown in Table 2. So, throughout the study period the highest value of RIP was appropriated to Moscow, which is quite natural, given the level of maintenance of the subject of financial, investment, intellectual, information and research resources. The three leaders also included Moscow and Kaluga regions. The lowest values correspond to the performance of Smolensk, Tambov, Bryansk and Kostroma regions, respectively. Research of dynamics of RIP of Kursk region has showed positive trends of steady growth: 1) the human potential of the region, due to the growing proportion of staff engaged in research and development, the total number of employed in the economy, and increasing the number of students per 10,000 person population; 2) technical and technological capabilities through increased innovation activity of enterprises of Kursk.

Table 2: Innovative potential of subjects of CFD

\begin{tabular}{|c||c|c|c|c|c||c|c||c|}
\hline Region & 2005 & 2009 & 2010 & 2011 & 2012 & 2013 & 2014 & 2015 \\
\hline Belgorod & 0,197 & 0,174 & 0,193 & 0,186 & 0,179 & 0,178 & 0,179 & 0,176 \\
\hline Bryansk & 0,149 & 0,148 & 0,144 & 0,133 & 0,154 & 0,150 & 0,151 & 0,154 \\
\hline Vladimir & 0,213 & 0,190 & 0,194 & 0,186 & 0,190 & 0,207 & 0,211 & 0,216 \\
\hline Voronezh & 0,248 & 0,229 & 0,240 & 0,221 & 0,248 & 0,258 & 0,266 & 0,273 \\
\hline Ivanovo & 0,151 & 0,159 & 0,158 & 0,139 & 0,144 & 0,165 & 0,167 & 0,169 \\
\hline Kaluga & 0,237 & 0,260 & 0,300 & 0,267 & 0,299 & 0,316 & 0,334 & 0,344 \\
\hline Kostroma & 0,133 & 0,091 & 0,125 & 0,110 & 0,116 & 0,116 & 0,125 & 0,124 \\
\hline Kursk & 0,152 & 0,158 & 0,156 & 0,160 & 0,172 & 0,191 & 0,200 & 0,213 \\
\hline Lipetsk & 0,146 & 0,188 & 0,198 & 0,184 & 0,169 & 0,193 & 0,195 & 0,201 \\
\hline Moscow & 0,342 & 0,316 & 0,348 & 0,325 & 0,349 & 0,377 & 0,395 & 0,408 \\
\hline Oryol & 0,184 & 0,133 & 0,183 & 0,166 & 0,156 & 0,154 & 0,163 & 0,158 \\
\hline Ryazan & 0,172 & 0,140 & 0,172 & 0,168 & 0,179 & 0,191 & 0,207 & 0,221 \\
\hline Smolensk & 0,121 & 0,152 & 0,158 & 0,140 & 0,146 & 0,168 & 0,173 & 0,178 \\
\hline Tambov & 0,148 & 0,155 & 0,135 & 0,158 & 0,177 & 0,187 & 0,197 & 0,217 \\
\hline Tver & 0,145 & 0,206 & 0,206 & 0,186 & 0,176 & 0,204 & 0,204 & 0,205 \\
\hline Tula & 0,170 & 0,165 & 0,179 & 0,158 & 0,185 & 0,193 & 0,202 & 0,209 \\
\hline Yaroslavl & 0,211 & 0,207 & 0,232 & 0,222 & 0,228 & 0,228 & 0,234 & 0,234 \\
\hline Moscow city & 0,625 & 0,585 & 0,592 & 0,591 & 0,635 & 0,617 & 0,626 & 0,635 \\
\hline
\end{tabular}

\section{CONCLUSIONS AND RECOMMENDATIONS}

Thus, the measures aimed at improving integrated RIP are necessary, taking into account the structural features. To do this, use the available potential, and identify internal opportunities and growth prospects, in order to accelerate the development, manufacturing, commercialization and transfer of innovation in the region.

One of the possible options for enhancing the effectiveness of the management of the region innovation system is the formation of the strategy of innovative development of the subject. This step includes the following stages.

1) The wording of the goals and priorities of in- 
novation development. General purpose, as a rule, serves the region's economy transition to an innovative path of development. Due to the fact that a particular region can claim to leadership at every stage of the innovation process, as well as, given the limited resources in the provision of innovative development, formulated the strategic priorities is to focus in a number of key areas.Firstly, the further development of the growth points that are already present in the subject and those fully supplied or available resources can be achieved without significant difficulty. Secondly, the maximum reduction in the backlog at those stages of the innovation process, which are at a low and very low level of development (eg, stage of commercialization or transfer of innovation in terms of the lack of necessary infrastructure).

2) The choice of target indicators of implementation of innovative strategies that can match the performance evaluation system of innovation potential of the region.

3) Determination of the mechanism of the impact on the region's innovation system. The instruments of the system implementation of the strategy in favor of normative-legal, institutional, infrastructural and financial support for innovative activities.

\section{REFERENCES}

1) Gumba H.M., Bakrunov Yu.O., Silka D. N. Creation of a technique of investment appeal of the region//Regional economy: theory and practice. 2007. No. 10. P. 33-37.

2) Gurakova N. S. The analysis of a macrostructure of industrial production in Russia for 2003-2009 and her tendencies for 2010 // Economy and management. 2010. No. 8(69). P. 111-116.

3) Emelianov S.G., Kabanon V.A., Kolmykova T.S. Innovations in the solution of problems of formation of new reproduction contours of national economy // Scientific and technical sheets of the St. Petersburg state polytechnical university. 2011. No. 121. P. 45-49.

4) Ivanova O. E. State and analysis of development of leading branches of the industry of Russia // Naukovedeniye Internet magazine. 2013. No. 4. P. 1-8.
5) Kokin A.S., Suyevalova M. A. The analysis of development of innovative small business within national innovative systems of foreign countries // Economy: yesterday, today, tomorrow. 2012. No. 3-4. P. 39-62.

6) Kolmykova T.S. Cognitive aspects of innovative development of economy // News of Southwest state university. 2012. No. 2-2 (41). P. 19a-22.

7) Kolmykova T.S., Merzlyakova E.A. State programs of modernization of a national industrial complex // News of Southwest state university. Economy series. Sociology. Management. 2013. No. 4. P. 22-30.

8) Kulakin G.K. Innovative processes: productivity in the form of technologies, goods, labor productivity // Modernization. Innovations. Development. 2013. No. 3 (15). P. 48-55.

9) Merzlyakova E.A. Conceptual bases of development of innovative capacity of the region under the influence of environmental factors // the Social and economic phenomena and processes. 2015. No. 6. P. 51-55.

10) Merzlyakova E.A. Management of development of innovative capacity of the region: methodical aspect // Social and economic phenomena and processes. 2015. No. 7. P. 84-90.

11) Risin I.E. Innovations in system of public administration by region economy // the Region: systems, economy, management. 2016. No. 1 (32). P. 127-130.

12) Silka D. N. Economic interests as incentive motives of business activity // Volga scientific magazine. 2013. No. 4.

13) Sirotkina N.V., Anisimov Yu.P. Indicative management of the innovative environment of modern business: monograph. - Voronezh: Voronezh in-t of innovative systems, 2008.

14) Titova M. V., Goncharov A.Yu., Sirotkina N. V. Regional innovative subsystem: assessment and planning of parameters of development // Modern economy: problems and decisions. 2015. No. 12 (72). P. 172-185.

15) Treshchevsky Yu.I., Litovkin M. V., I.V's Terzi. Innovative development of regions of Russia during growth of an economic environment // the Region: systems, economy, manage- 
ment. 2016. No. 1 (32). P. 33-40.

16) Financial aspects of investment and innovative development: the monograph / V. V. Alekseev, O. V. Belyaev, O. G. Larin, E.A. Merzlyakov, I.V. Milgunov, etc. - Kursk: Business polygraphy, 2014. - $240 \mathrm{p}$.

17) Harchenko E.V. System transformation of economy: transition to innovative way of development of regional economy//Innovative Region Bulletin.

Paper sent to revision: 26.07.2017.

Paper ready for publication: 02.09.2017. 